\title{
Spatial distributions of heating, cooling, and industrial degree-days in Turkey
}

\author{
I. Yildiz ${ }^{1}$ and B. Sosaoglu ${ }^{2}$ \\ ${ }^{1}$ Department of Earth Sciences, University of Windsor, Windsor, Ontario, Canada \\ ${ }^{2}$ Toraman Biothermal Systems Inc., Ancaster, Ontario, Canada
}

\begin{abstract}
Summary
The degree-day method is commonly used to estimate energy consumption for heating and cooling in residential, commercial and industrial buildings, as well as in greenhouses, livestock facilities, storage facilities and warehouses. This article presents monthly and yearly averages and spatial distributions of heating, cooling, and industrial degree-days at the base temperatures of $18^{\circ} \mathrm{C}$ and $20^{\circ} \mathrm{C}$, $18^{\circ} \mathrm{C}$ and $24^{\circ} \mathrm{C}$, and $7{ }^{\circ} \mathrm{C}$ and $13{ }^{\circ} \mathrm{C}$, respectively; as well as the corresponding number of days in Turkey. The findings presented here will facilitate the estimation of heating and cooling energy consumption for any residential, commercial and industrial buildings in Turkey, for any period of time (monthly, seasonal, etc.). From this analysis it will also be possible to compare and design alternative building systems in terms of energy efficiencies. If one prefers to use set point temperatures to indicate the resumption of the heating season would also be possible using the provided information in this article. In addition, utility companies and manufacturing/marketing companies of HVAC systems would be able to easily determine the demand, marketing strategies and policies based on the findings in this study.
\end{abstract}

\section{Introduction}

The degree-day method is commonly used to estimate energy consumption for heating and cooling in residential, commercial and industrial buildings, as well as in greenhouses, live- stock facilities, storage facilities and warehouses (Environment Canada, 1978, 1987; ASHRAE, 1989; Yesilirmak and Yildiz, 2001; Yildiz and Yesilirmak, 2001). This approach is also used for estimating plant and insect growth, and freezing and thawing of soil and water surfaces (Thomas, 1953; Ramirez, 1964; McKay et al., 1967; Neild and Seeley, 1976; Environment Canada, 1978, 1987, 1990; Edey, 1980; Agriculture Canada, 1993; Bootsma, 1994; Lenihan and Neilson, 1995; Sykes and Prentice, 1996; Singh et al., 1998; Yildiz, 1998; Yildiz et al., 1998).

Estimating energy requirements and fuel consumption for heating, ventilating and air conditioning (HVAC) systems at any temporal scale can be difficult due to the many dynamic factors which influence energy requirements. Therefore, the most reliable method for estimating future energy requirements of a building is the past operating experience. If such records do not exist, then calculations for estimating energy requirements for HVAC systems are often necessary, especially for new buildings.

Turkey is one of the pilot regions chosen by the Intergovernmental Panel on Climate Change (IPCC) (IPCC, 1991). Several general circulation models (GCMs) have been run over the country, and projections have been generated. Based on 
these projections, a temperature increase of approximately $2{ }^{\circ} \mathrm{C}$ (winter) to $3{ }^{\circ} \mathrm{C}$ (summer) is expected in the future. However, the findings of Kadioglu (1997) based on a trend analysis of climate series in Turkey, are not in agreement with the GCM projections. Due to the fact that climate is changing, updating climatic design parameters becomes vital. In an earlier study, engineering weather data for designing HVAC systems for buildings were developed for Turkey (Yildiz and Yesilirmak, 1998). To complement Yildiz and Yesilirmak (1998), the study presented in this article was performed in order to develop heating, cooling, and industrial degree-days as an integral part of an extensive study, aimed at determining heating, cooling, industrial, freezing and thawing degree-days, as well as growing degree-days at different base temperatures across Turkey. The findings provided in this article will facilitate designers in estimating monthly, seasonal, and annual heating and cooling energy consumptions for residential, commercial and industrial buildings. It will also enable the comparison and design of alternative building systems in terms of energy efficiencies.

\section{Materials and methods}

\subsection{Materials}

In this study, the number of heating, cooling and industrial degree-days and corresponding number of days were determined for 100 different locations across Turkey (Fig. 1). All cities were included in this study, as well as some towns, which exhibited some kind of importance and differences in microclimate (e.g. the tourist-

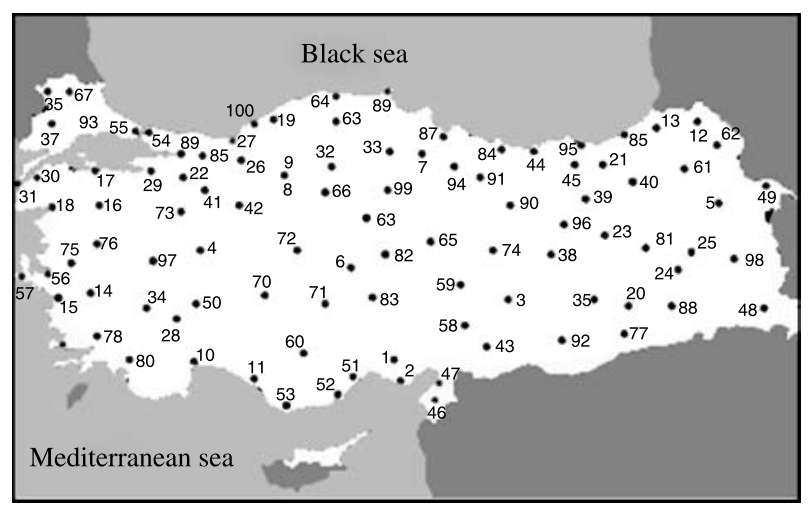

Fig. 1. Station locations used in the study oriented towns of Kuşadası and Bodrum, as well as the Dalaman Airport, were included in this study along with the nearby cities of Aydın and Muğla). Meteorological data for each location were provided by the State Meteorological Service of Turkey (DMI). The daily dry-bulb temperature values for a 30-year period (1975-2004) were used. If the data for any location were not sufficient, reliable or available electronically, then the location was not included in the study.

\subsection{Degree-day method}

Since many factors which influence the energy requirements of buildings are dynamic and vary in time, the calculations that take all variations into account are quite complex. Therefore, estimating energy requirements and fuel consumption of HVAC systems for either short or long-term operation can be difficult. As a result, the records of past energy requirements and/or fuel consumption for a particular residence are the best basis for estimating future energy use. However, when past records are not available, data from similar local dwellings can be used with caution. Since people have different living habits, even identical residences can have very different energy use patterns. Therefore, energy consumption must often be estimated from computed heating or cooling loads.

Any estimating method produces a much more reliable result over a long period of operation than over a short period. Almost all methods provide a reasonable result over a full annual heating and/or cooling season, but estimates for shorter periods, for example, a month, can be inaccurate.

The degree-day method for estimating heating energy requirements is based on the assumption that, on a long-term average, energy consumption will be proportional to the difference between the mean daily temperature and a heating base temperature of $18^{\circ} \mathrm{C}$ or $20^{\circ} \mathrm{C}$. For estimating cooling energy requirements, this is based on the assumption that energy consumption will be proportional to the difference between the mean daily temperature and a cooling base temperature of $18{ }^{\circ} \mathrm{C}$ or $24^{\circ} \mathrm{C}$ (Environment Canada, 1982, 1988). The difference between the mean daily temperature and the base temperature is called a "degree-day" (ASHRAE, 1989). In determin- 
ing the heating and cooling base temperatures for buildings, solar and internal heat gains for buildings are taken into account. For example, if the internal temperature of a residential building is to be maintained at $21^{\circ} \mathrm{C}$, it is assumed that the solar and internal gains maintain this temperature until the external temperature drops below $18^{\circ} \mathrm{C}$ (ASHRAE, 1989). Therefore, the most commonly used base temperature for residential heating is $18^{\circ} \mathrm{C}$ (ASHRAE, 1989; Williams and MacKay, 1970; Wilson, 1973). In other words, on a day when the mean external temperature is $10^{\circ} \mathrm{C}$ below $18^{\circ} \mathrm{C}$, twice as much energy is consumed as on days when the mean temperature is $5^{\circ} \mathrm{C}$ below $18^{\circ} \mathrm{C}$. An equation has been developed for this concept stating that energy consumption is directly proportional to the number of degreedays in the estimation period.

For industrial degree-days base temperatures of $7^{\circ} \mathrm{C}$ or $13^{\circ} \mathrm{C}$ are used (ASHRAE, 1989; Environment Canada, 1982, 1988; Williams and MacKay, 1970; Wilson, 1973). For example, if the internal temperature is to be maintained at $15-16^{\circ} \mathrm{C}$ in an industrial building, it is assumed that the solar and internal gains maintain temperature at this threshold until the external temperature drops below $13{ }^{\circ} \mathrm{C}$. Similarly, if the internal temperature is to be maintained at $10^{\circ} \mathrm{C}$ in an industrial building, it is again, assumed that solar and internal gains maintain this temperature until the external temperature drops below $7^{\circ} \mathrm{C}$. The base temperature of $7^{\circ} \mathrm{C}$ is also used for determining heating energy consumption in greenhouses (Wilson, 1973).

\subsection{Determination of heating degree-days and corresponding number of days}

This article presents the heating, cooling and industrial degree-day components of a much more extensive study. Daily heating degree-day accumulation $\left(t_{\mathrm{h}}\right)$ is defined as the deviation of the mean temperature from a heating base temperature of $18{ }^{\circ} \mathrm{C}$ or $20^{\circ} \mathrm{C}$ (Eq. (1)), and has the same unit as temperature. When the mean temperature is greater than the base temperature, the degree-day for that day is zero.

$t_{\mathrm{h}}=t_{\mathrm{b}}-t_{\mathrm{d}}$

where $t_{\mathrm{b}}$ is the base temperature $\left(18^{\circ} \mathrm{C}\right.$ or $\left.20^{\circ} \mathrm{C}\right)$, and $t_{\mathrm{d}}$ is the mean daily air temperature. The mean daily air temperature, $t_{\mathrm{d}}$, is defined as:

$t_{\mathrm{d}}=\left(t_{\max }-t_{\min }\right) / 2$

where $t_{\max }$ is the daily maximum temperature, and $t_{\min }$ is the daily minimum temperature.

For a certain period of time (weekly, monthly, seasonal, annual, etc.), accumulated heating degree-day $\left(D_{\mathrm{h}}\right)$ is defined as:

$D_{\mathrm{h}}=\sum_{j=1}^{N}\left(t_{\mathrm{h}}\right)_{j} \quad\left\{\begin{array}{l}\text { If } t_{\mathrm{d}}<t_{\mathrm{b}} \text { then } t_{\mathrm{h}}=t_{\mathrm{b}}-t_{\mathrm{d}} \\ \text { else } t_{\mathrm{h}}=0\end{array}\right\}$

where $N$ is defined as the period of time (number of days).

The corresponding number of days for heating degree-days were also determined and are presented in this article. Using the corresponding number of days, one can estimate the length of the heating season for a residential and commercial building at any particular location. The corresponding number of days for the accumulated heating degree-days for any period of time is determined by summing the days with $t_{\mathrm{d}}$ less than $t_{\mathrm{b}}$.

The $D_{\mathrm{h}}$ findings presented in Table 1 do not have any set point temperature to define the resumption of the heating season. However, the $D_{\mathrm{h}}$ findings for the base temperatures of $18^{\circ} \mathrm{C}$ and $20^{\circ} \mathrm{C}$, presented in Table 2 , have set point temperatures of $12^{\circ} \mathrm{C}$ and $15^{\circ} \mathrm{C}$, respectively. When the mean daily temperature drops below these set point temperatures the heating season is considered to have resumed, heating degree days accumulate, and the corresponding number of days is used to estimate the length of the heating season. Using the $D_{\mathrm{h}}$ values for the base temperature of $20^{\circ} \mathrm{C}$ and the set point temperature of $12^{\circ} \mathrm{C}$, the heating regions were established (Table 3 ); the distributions are presented in Fig. 2. In several earlier studies, heating degree-days for Turkey were determined at different base temperatures for different locations (Yener and Gurdil, 1987; Dagsoz, 1995). However, in these studies, either only a couple of years' weather data were used, or no information was available. Even though these studies provided quite valuable information, they were limited in terms of the base temperatures and the set point temperatures investigated. In another study, even though it did not have any design purposes, seasonal heating and cooling 


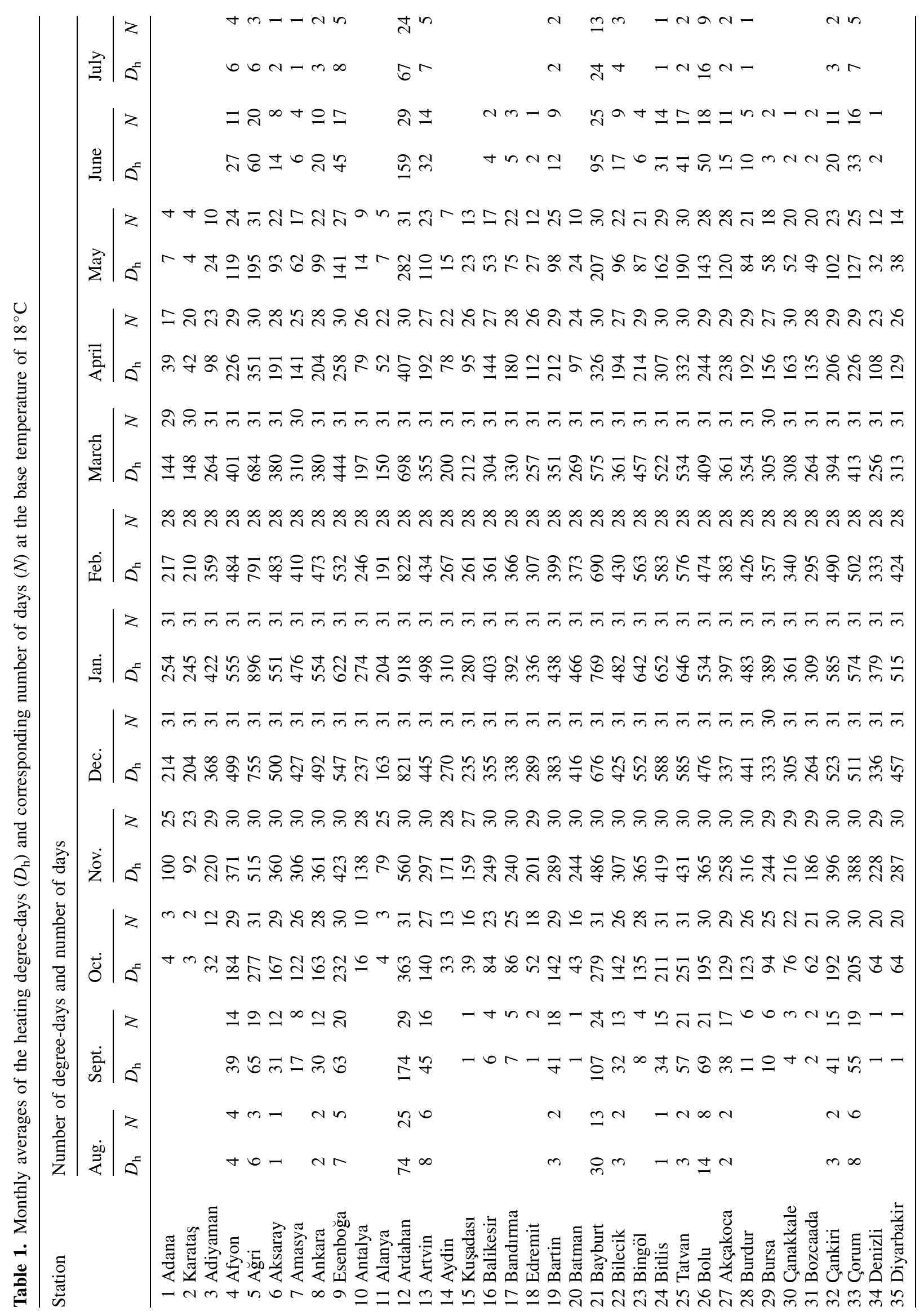


Table 2. Annual average heating degree-days $\left(D_{\mathrm{h}}\right)$ and corresponding number of days $(N)$ for different base temperature and set point temperature combinations

\begin{tabular}{|c|c|c|c|c|c|c|}
\hline \multirow[t]{3}{*}{ Station } & \multicolumn{6}{|c|}{ Degree-days and number of days } \\
\hline & \multicolumn{2}{|c|}{$t_{\mathrm{b}}=18^{\circ} \mathrm{C} / 12^{\circ} \mathrm{C}$} & \multicolumn{2}{|c|}{$t_{\mathrm{b}}=20^{\circ} \mathrm{C} / 12^{\circ} \mathrm{C}$} & \multicolumn{2}{|c|}{$t_{\mathrm{b}}=20^{\circ} \mathrm{C} / 15^{\circ} \mathrm{C}$} \\
\hline & $D_{\mathrm{h}}$ & $N$ & $D_{\mathrm{h}}$ & $N$ & $D_{\mathrm{h}}$ & $N$ \\
\hline 1 Adana & 697 & 81 & 858 & 81 & 1178 & 129 \\
\hline 2 Karataş & 658 & 75 & 808 & 75 & 1128 & 124 \\
\hline 3 Adiyaman & 1603 & 137 & 1877 & 137 & 2086 & 169 \\
\hline 4 Afyon & 2706 & 192 & 3090 & 192 & 3315 & 227 \\
\hline 5 Ağri & 4420 & 227 & 4874 & 227 & 5068 & 257 \\
\hline 6 Aksaray & 2565 & 181 & 2927 & 181 & 3147 & 215 \\
\hline 7 Amasya & 2061 & 159 & 2379 & 159 & 2613 & 195 \\
\hline 8 Ankara & 2573 & 184 & 2941 & 184 & 3157 & 217 \\
\hline 9 Esenboğa & 3093 & 207 & 3506 & 207 & 3752 & 245 \\
\hline 10 Antalya & 901 & 102 & 1104 & 102 & 1449 & 154 \\
\hline 11 Alanya & 454 & 57 & 568 & 57 & 1022 & 127 \\
\hline 12 Ardahan & 5094 & 267 & 5628 & 267 & 5895 & 308 \\
\hline 13 Artvin & 2305 & 176 & 2658 & 176 & 2920 & 217 \\
\hline 14 Aydin & 1077 & 108 & 1294 & 108 & 1582 & 152 \\
\hline 15 Kuşadası & 974 & 98 & 1170 & 98 & 1530 & 154 \\
\hline 16 Balikesir & 1724 & 146 & 2016 & 146 & 2285 & 188 \\
\hline 17 Bandırma & 1769 & 153 & 2075 & 153 & 2355 & 196 \\
\hline 18 Edremit & 1322 & 125 & 1571 & 125 & 1864 & 170 \\
\hline 19 Bartin & 2109 & 175 & 2458 & 175 & 2735 & 217 \\
\hline 20 Batman & 1748 & 141 & 2030 & 141 & 2231 & 172 \\
\hline 21 Bayburt & 4025 & 234 & 4492 & 234 & 4742 & 273 \\
\hline 22 Bilecik & 2256 & 172 & 2600 & 172 & 2854 & 211 \\
\hline 23 Bingöl & 2865 & 183 & 3231 & 183 & 3414 & 211 \\
\hline 24 Bitlis & 3333 & 210 & 3753 & 210 & 3942 & 239 \\
\hline 25 Tatvan & 3344 & 217 & 3777 & 217 & 3957 & 245 \\
\hline 26 Bolu & 2717 & 199 & 3115 & 199 & 3395 & 243 \\
\hline 27 Akçakoca & 2004 & 172 & 2348 & 172 & 2641 & 217 \\
\hline 28 Burdur & 2251 & 175 & 2601 & 175 & 2811 & 208 \\
\hline 29 Bursa & 1699 & 145 & 1989 & 145 & 2266 & 188 \\
\hline 30 Çanakkale & 1548 & 139 & 1826 & 139 & 2140 & 187 \\
\hline 31 Bozcaada & 1242 & 120 & 1482 & 120 & 1842 & 176 \\
\hline 32 Çankiri & 2745 & 191 & 3127 & 191 & 3350 & 225 \\
\hline 33 Çorum & 2819 & 198 & 3214 & 198 & 3452 & 235 \\
\hline 34 Denizli & 1520 & 135 & 1791 & 135 & 2035 & 173 \\
\hline 35 Diyarbakir & 2054 & 155 & 2364 & 155 & 2553 & 184 \\
\hline
\end{tabular}

Table 3. Heating regions in Turkey $\left(t_{\mathrm{b}}=20^{\circ} \mathrm{C} / 12^{\circ} \mathrm{C}\right)$

\begin{tabular}{lllll}
\hline Region & Degree-day main-group & Degree-day sub-group & Altitude & General distribution \\
\hline I & $<1500$ & $<1500$ & $<100 \mathrm{~m}$ & Aegean and Coastal Mediterranean \\
II & $1500-2500$ & $1500-2000$ & $<100 \mathrm{~m}$ & Coastal Black Sea \\
& & $2000-2500$ & $<100 \mathrm{~m}$ & Black Sea and Marmara \\
& & $2000-2500$ & $500-1000 \mathrm{~m}$ & Southeastern Anatolia \\
III & $2500-3500$ & $2500-3000$ & $500-1000 \mathrm{~m}$ & Multiple Regions \\
& & $3000-3500$ & $500-1000 \mathrm{~m}$ & Transitional Regions \\
& & $3000-3500$ & $1000-1500 \mathrm{~m}$ & Central Anatolia \\
IV & 35500 & $3500-4000$ & $1000-1500 \mathrm{~m}$ & Central Anatolia (high altitudes) \\
& & $3500-4000$ & $>1500$ & Eastern Anatolia \\
& & $>4000$ & $>1500$ & Eastern Anatolia (north) \\
\hline
\end{tabular}




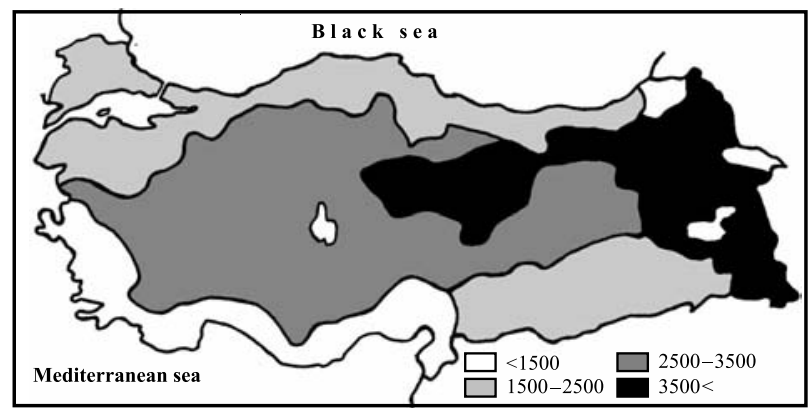

Fig. 2. Distribution of the heating regions in Turkey $\left(t_{\mathrm{b}}=20^{\circ} \mathrm{C} / 12^{\circ} \mathrm{C}\right)$

degree-days in Turkey were determined in the context of climate change (Kadioglu et al., 2001). Therefore, it was one of the objectives of this study to develop up-to-date heating degree-day information for different base temperature and set point temperature combinations across Turkey using reliable long-term weather data.

\subsection{Determination of cooling degree-days and corresponding number of days}

Daily cooling degree-days $\left(t_{\mathrm{c}}\right)$ are defined as the deviation of the mean temperature from a cooling base temperature of $18^{\circ} \mathrm{C}$ or $24^{\circ} \mathrm{C}$ (Eq. (4)), and has the same unit as temperature. When the mean temperature is below the base temperature, then the cooling degree-day for that day is zero.

$$
t_{\mathrm{c}}=t_{\mathrm{d}}-t_{\mathrm{b}}
$$

Table 4. Annual averages of the cooling degree-days at the base temperatures of $18{ }^{\circ} \mathrm{C}$ and $24{ }^{\circ} \mathrm{C}$

\begin{tabular}{|c|c|c|c|c|c|c|c|}
\hline \multirow[t]{2}{*}{ Station } & \multicolumn{2}{|c|}{ Lat. } & \multicolumn{2}{|c|}{ Longit. } & \multirow{2}{*}{$\begin{array}{l}\text { Altitude } \\
\text { meter }\end{array}$} & \multicolumn{2}{|c|}{ Number of degree-days } \\
\hline & $\circ$ & 1 & $\circ$ & 1 & & $t_{\mathrm{b}}=18^{\circ} \mathrm{C}$ & $t_{\mathrm{b}}=24^{\circ} \mathrm{C}$ \\
\hline 1 Adana & 36 & 59 & 35 & 21 & 27 & 1376 & 404 \\
\hline 2 Karataş & 36 & 34 & 35 & 23 & 22 & 1235 & 302 \\
\hline 3 Adiyaman & 37 & 45 & 38 & 17 & 672 & 1441 & 582 \\
\hline 4 Afyon & 38 & 45 & 30 & 32 & 1034 & 359 & 21 \\
\hline 5 A ̆ğri & 39 & 44 & 43 & 03 & 1632 & 240 & 10 \\
\hline 6 Aksaray & 38 & 23 & 34 & 03 & 965 & 465 & 42 \\
\hline 7 Amasya & 40 & 39 & 35 & 51 & 412 & 589 & 66 \\
\hline 8 Ankara & 39 & 57 & 32 & 53 & 890 & 449 & 44 \\
\hline 9 Esenboğa & 40 & 07 & 33 & 00 & 949 & 259 & 11 \\
\hline 10 Antalya & 36 & 53 & 30 & 42 & 42 & 1129 & 310 \\
\hline 11 Alanya & 36 & 33 & 32 & 00 & 7 & 1178 & 282 \\
\hline 12 Ardahan & 41 & 07 & 42 & 43 & 1829 & 21 & 0 \\
\hline 13 Artvin & 41 & 11 & 41 & 49 & 628 & 252 & 10 \\
\hline 14 Aydin & 37 & 51 & 27 & 51 & 56 & 1151 & 320 \\
\hline 15 Kuşadası & 37 & 52 & 27 & 15 & 22 & 841 & 133 \\
\hline 16 Balikesir & 39 & 39 & 27 & 52 & 146 & 687 & 86 \\
\hline 17 Bandırma & 40 & 21 & 27 & 58 & 58 & 540 & 30 \\
\hline 18 Edremit & 39 & 35 & 27 & 01 & 21 & 916 & 199 \\
\hline 19 Bartin & 41 & 38 & 32 & 20 & 30 & 303 & 5 \\
\hline 20 Batman & 37 & 53 & 41 & 07 & 540 & 1347 & 567 \\
\hline 21 Bayburt & 40 & 15 & 40 & 14 & 1584 & 112 & 3 \\
\hline 22 Bilecik & 40 & 09 & 29 & 58 & 539 & 385 & 23 \\
\hline 23 Bingöl & 38 & 52 & 40 & 30 & 1177 & 765 & 176 \\
\hline 24 Bitlis & 38 & 22 & 42 & 06 & 1573 & 343 & 18 \\
\hline 25 Tatvan & 38 & 29 & 42 & 18 & 1664 & 240 & 5 \\
\hline 26 Bolu & 40 & 44 & 31 & 36 & 743 & 160 & 1 \\
\hline 27 Akçakoca & 41 & 05 & 31 & 10 & 10 & 265 & 2 \\
\hline 28 Burdur & 37 & 40 & 30 & 20 & 967 & 595 & 76 \\
\hline 29 Bursa & 40 & 11 & 29 & 04 & 100 & 643 & 74 \\
\hline 30 Çanakkale & 40 & 08 & 26 & 24 & 6 & 668 & 76 \\
\hline 31 Bozcaada & 39 & 50 & 26 & 04 & 28 & 538 & 26 \\
\hline 32 Çankiri & 40 & 36 & 33 & 37 & 751 & 392 & 31 \\
\hline 33 Çorum & 40 & 33 & 34 & 57 & 776 & 231 & 7 \\
\hline 34 Denizli & 37 & 47 & 29 & 05 & 425 & 991 & 250 \\
\hline 35 Diyarbakir & 37 & 54 & 40 & 14 & 677 & 1286 & 514 \\
\hline
\end{tabular}




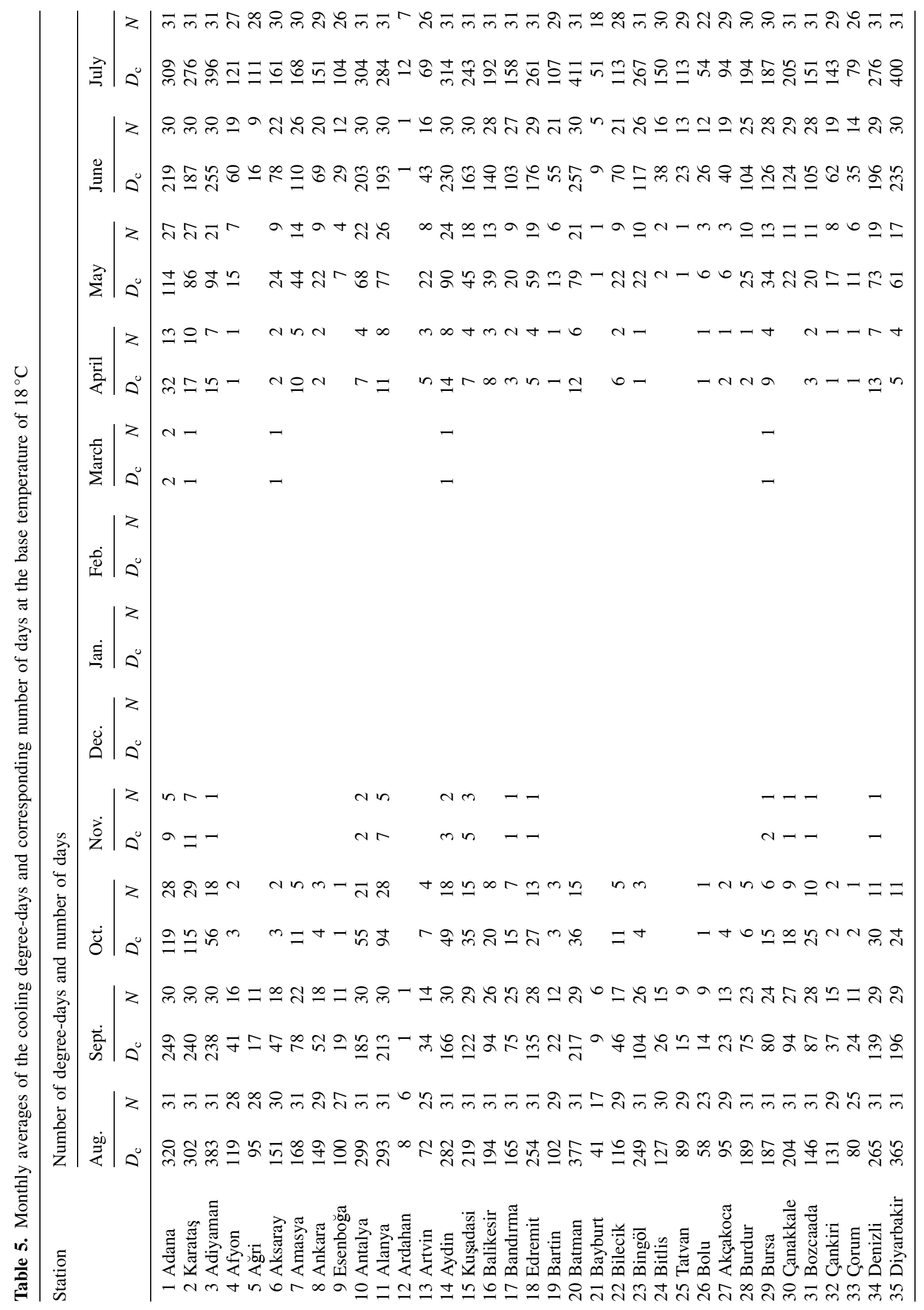


where $t_{\mathrm{b}}$ is the base temperature $\left(18^{\circ} \mathrm{C}\right.$ or $\left.24^{\circ} \mathrm{C}\right)$, and $t_{\mathrm{d}}$ is the mean daily air temperature. The mean temperature, $t_{\mathrm{d}}$, was defined earlier in Eq. (2).

For a certain period of time (weekly, monthly, seasonal, annual, etc.), accumulated cooling degree-day $\left(D_{\mathrm{c}}\right)$ is defined as:

$D_{\mathrm{c}}=\sum_{j=1}^{N}\left(t_{\mathrm{c}}\right)_{j} \quad\left\{\begin{array}{l}\text { If } t_{\mathrm{d}}>t_{\mathrm{b}} \text { then } t_{\mathrm{c}}=t_{\mathrm{b}}-t_{\mathrm{d}} \\ \text { else } t_{\mathrm{c}}=0\end{array}\right\}$

where $N$ is the period of time (number of days). The corresponding number of days for the accumulated cooling degree-days for any period of time is determined by summing the days with $t_{\mathrm{d}}$ greater than $t_{\mathrm{b}}$. Also in this study, the corresponding number of cooling degree-days were determined and are presented in this article. Using the corresponding number of days, one can estimate the length of the cooling season for any particular location.

\subsection{Determination of industrial degree-days and corresponding number of days}

The daily industrial degree-day $\left(D_{\mathrm{i}}\right)$ is defined as the deviation of the mean temperature from a heating base temperature of $7{ }^{\circ} \mathrm{C}$ or $13^{\circ} \mathrm{C}$ (Eq. (1)).

Table 6. Monthly averages of the cooling degree-days and corresponding number of days at the base temperature of $24{ }^{\circ} \mathrm{C}$

\begin{tabular}{|c|c|c|c|c|c|c|c|c|c|c|c|c|c|c|c|c|c|c|c|c|c|c|c|}
\hline \multirow[t]{3}{*}{ Station } & \multicolumn{23}{|c|}{ Number of degree-days and number of days } \\
\hline & \multicolumn{2}{|c|}{ Aug. } & \multicolumn{2}{|c|}{ Sept. } & \multicolumn{2}{|c|}{ Oct. } & Nov. & \multicolumn{2}{|c|}{ Dec. } & \multicolumn{2}{|c|}{ Jan. } & \multicolumn{2}{|c|}{ Feb. } & \multicolumn{2}{|c|}{ March } & \multicolumn{2}{|c|}{ April } & \multicolumn{2}{|c|}{ May } & \multicolumn{2}{|c|}{ June } & \multicolumn{2}{|l|}{ July } \\
\hline & $D_{\mathrm{c}}$ & $N$ & $D_{\mathrm{c}}$ & $N$ & $D_{\mathrm{c}}$ & $N$ & $D_{\mathrm{c}} \quad N$ & $D_{\mathrm{c}}$ & $N$ & $D_{\mathrm{c}}$ & $N$ & $D_{\mathrm{c}}$ & $N$ & $D_{\mathrm{c}}$ & $N$ & $D_{\mathrm{c}}$ & $N$ & $D_{\mathrm{c}}$ & $N$ & $D_{\mathrm{c}}$ & $N$ & $D_{\mathrm{c}}$ & $N$ \\
\hline 1 Adana & 134 & 31 & 73 & 27 & 9 & 7 & & & & & & & & & & 1 & 1 & 14 & 6 & 49 & 24 & 123 & 31 \\
\hline 2 Karataş & 116 & 31 & 63 & 27 & 7 & 5 & & & & & & & & & & & & 5 & 3 & 22 & 18 & 90 & 31 \\
\hline 3 Adiyaman & 197 & 31 & 71 & 23 & 3 & 2 & & & & & & & & & & & & 13 & 6 & 89 & 23 & 210 & 31 \\
\hline 4 Afyon & 7 & 6 & 1 & 1 & & & & & & & & & & & & & & & & 3 & 2 & 11 & 8 \\
\hline 5 Ağri & 3 & 3 & & & & & & & & & & & & & & & & & & & & 8 & 5 \\
\hline 6 Aksaray & 15 & 10 & 1 & 1 & & & & & & & & & & & & & & 1 & 1 & 5 & 3 & 21 & 13 \\
\hline 7 Amasya & 22 & 12 & 5 & 3 & & & & & & & & & & & & & & 3 & 2 & 12 & 7 & 23 & 12 \\
\hline 8 Ankara & 18 & 10 & 2 & 2 & & & & & & & & & & & & & & & & 4 & 3 & 21 & 12 \\
\hline 9 Esenboğa & 5 & 4 & & & & & & & & & & & & & & & & & & & & 6 & 5 \\
\hline 10 Antalya & 113 & 31 & 26 & 16 & 2 & 1 & & & & & & & & & & & & 4 & 3 & 44 & 18 & 119 & 30 \\
\hline 11 Alanya & 107 & 31 & 40 & 22 & 3 & 2 & & & & & & & & & & & & 3 & 2 & 29 & 18 & 99 & 31 \\
\hline 12 Ardahan & & & & & & & & & & & & & & & & & & & & & & & \\
\hline 13 Artvin & 3 & 2 & 2 & 1 & & & & & & & & & & & & & & 1 & 1 & 1 & 1 & 4 & 2 \\
\hline 14 Aydin & 97 & 29 & 20 & 12 & 1 & 1 & & & & & & & & & & & & 8 & 5 & 64 & 23 & 129 & 30 \\
\hline 15 Kuşadası & 42 & 22 & 7 & 5 & 1 & 1 & & & & & & & & & & & & 2 & 1 & 19 & 11 & 62 & 26 \\
\hline 16 Balikesir & 30 & 18 & 6 & 5 & & & & & & & & & & & & & & 2 & 1 & 18 & 10 & 30 & 17 \\
\hline 17 Bandırma & 10 & 11 & 1 & 1 & & & & & & & & & & & & & & 1 & 1 & 7 & 5 & 11 & 9 \\
\hline 18 Edremit & 73 & 26 & 13 & 8 & & & & & & & & & & & & & & 2 & 2 & 30 & 15 & 81 & 27 \\
\hline 19 Bartin & 1 & 2 & & & & & & & & & & & & & & & & & & 1 & 1 & 2 & 2 \\
\hline 20 Batman & 191 & 31 & 55 & 21 & 1 & 1 & & & & & & & & & & & & 7 & 4 & 88 & 24 & 225 & 31 \\
\hline 21 Bayburt & 1 & 1 & & & & & & & & & & & & & & & & & & & & 2 & 2 \\
\hline 22 Bilecik & 6 & 5 & 2 & 1 & & & & & & & & & & & & & & 1 & 1 & 4 & 3 & 9 & 5 \\
\hline 23 Bingöl & 70 & 27 & 6 & 5 & & & & & & & & & & & & & & & & 13 & 8 & 88 & 27 \\
\hline 24 Bitlis & 4 & 5 & & & & & & & & & & & & & & & & & & & & 13 & 10 \\
\hline 25 Tatvan & 1 & 1 & & & & & & & & & & & & & & & & & & & & 4 & 4 \\
\hline 26 Bolu & 1 & 1 & & & & & & & & & & & & & & & & & & & & 1 & 1 \\
\hline 27 Akçakoca & 1 & 1 & & & & & & & & & & & & & & & & & & & & 1 & 2 \\
\hline 28 Burdur & 29 & 18 & 2 & 2 & & & & & & & & & & & & & & & & 8 & 6 & 37 & 17 \\
\hline 29 Bursa & 27 & 17 & 3 & 3 & & & & & & & & & & & & & & 2 & 1 & 13 & 8 & 28 & 17 \\
\hline 30 Çanakkale & 33 & 21 & 2 & 3 & & & & & & & & & & & & & & & & 7 & 6 & 34 & 21 \\
\hline 31 Bozcaada & 6 & 6 & 1 & 1 & 1 & 1 & & & & & & & & & & & & & & 5 & 4 & 13 & 6 \\
\hline 32 Çankiri & 12 & 8 & 1 & 1 & & & & & & & & & & & & & & & & 3 & 2 & 16 & 11 \\
\hline 33 Çorum & 3 & 3 & 1 & & & & & & & & & & & & & & & & & 1 & 1 & 3 & 2 \\
\hline 34 Denizli & 84 & 27 & 14 & 8 & 1 & 1 & & & & & & & & & & & & 7 & 4 & 47 & 18 & 97 & 27 \\
\hline 35 Diyarbakir & 179 & 31 & 43 & 18 & & & & & & & & & & & & & & 4 & 3 & 73 & 21 & 214 & 31 \\
\hline
\end{tabular}


When the mean temperature is above the base temperature, then the degree-day for that day is zero.

$t_{\mathrm{i}}=t_{\mathrm{b}}-t_{\mathrm{d}}$

where $t_{\mathrm{b}}$ is the base temperature $\left(7^{\circ} \mathrm{C}\right.$ or $\left.13^{\circ} \mathrm{C}\right)$, and $t_{\mathrm{d}}$ is the mean daily air temperature. The mean temperature, $t_{\mathrm{d}}$, was defined in Eq. (2).

For a certain period of time (daily, weekly, monthly, seasonal, annual, etc.) the accumulated industrial degree-day is defined as:

$D_{\mathrm{i}}=\sum_{j=1}^{N}\left(t_{\mathrm{i}}\right)_{j} \quad\left\{\begin{array}{l}\text { If } t_{\mathrm{d}}>t_{\mathrm{b}} \text { then } t_{\mathrm{i}}=t_{\mathrm{b}}-t_{\mathrm{d}} \\ \text { else } t_{\mathrm{i}}=0\end{array}\right\}$

where $N$ is defined as the period of time (number of days).

The corresponding number of industrial degreedays were also determined and are presented in this article. Using the corresponding number of days, one can estimate the length of the heating season for industrial buildings at any location. The corresponding number of days for the accumulated industrial degree-days for any period of time is determined by summing the days with $t_{\mathrm{d}}$ less than $t_{\mathrm{b}}$.

\section{Results and discussion}

Due to the space limitation, tabulated degreeday values for only 35 stations are presented in alphabetical order in this article (Tables 1, 2, 4, 5, 6, 8, and 9). Readers are referred to Yildiz and Sosaoglu (2006) for the other stations which are not presented here.

\subsection{Heating degree-days}

Table 1 shows the monthly averages of heating degree-days $\left(D_{\mathrm{h}}\right)$ and their corresponding number of days which were determined for 100 different locations at the base temperature of $18^{\circ} \mathrm{C}$. The findings show that at the base temperature of $18^{\circ} \mathrm{C}$, relatively high $D_{\mathrm{h}}$ values were observed at Ardahan, Sarikamis, Kars, Agri and Erzurum (northeast region of Turkey) (Table 1). It was also observed that intensive monthly $D_{\mathrm{h}}$ accumulations were generally realized in the months of December, January, and February. Conversely, very low monthly $D_{\mathrm{h}}$ accumulations were observed at Alanya, Iskenderun, Mersin, Anamur, and Silifke (Mediterranean coastal cities).
The $D_{h}$ findings which were presented in Table 2 for the base temperatures of $18^{\circ} \mathrm{C}$ and $20^{\circ} \mathrm{C}$ had a temperature set point of $12^{\circ} \mathrm{C}$ or $15^{\circ} \mathrm{C}$; that is, heating would not start in the fall until the mean daily temperature dropped below the set point temperature. Therefore, these findings were naturally lower than the $D_{\mathrm{h}}$ values determined for the case when no set points temperatures were used. In this study, an attempt was made to develop heating regions for the base temperature of $20^{\circ} \mathrm{C}$ and the set point temperature of $12{ }^{\circ} \mathrm{C}$. These regions and their corresponding numerical $D_{\mathrm{h}}$ ranges are presented in Table 3 along with the general spatial distributions in Fig. 2. Based on these findings, the lowest energy consumption for heating occurs in the coastal Aegean and Mediterranean regions, while the highest energy consumption is observed in the regions which experience severe winter

Table 7. Cooling regions in Turkey $\left(t_{\mathrm{b}}=18^{\circ} \mathrm{C}\right)$

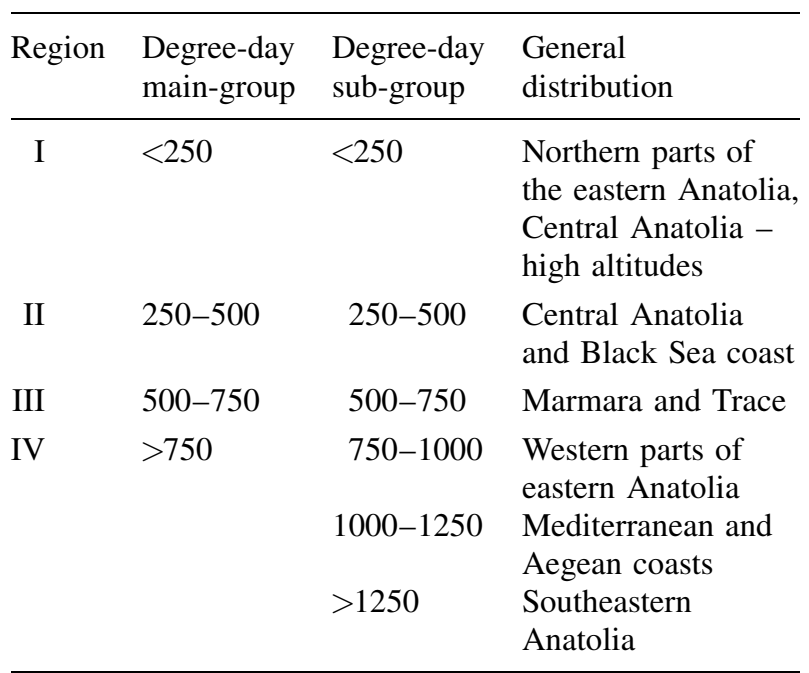

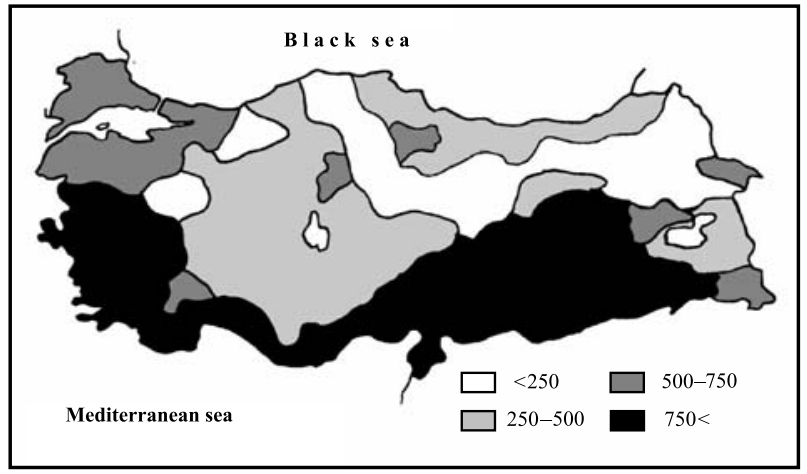

Fig. 3. Distribution of the cooling regions in Turkey $\left(t_{\mathrm{b}}=18^{\circ} \mathrm{C}\right)$ 


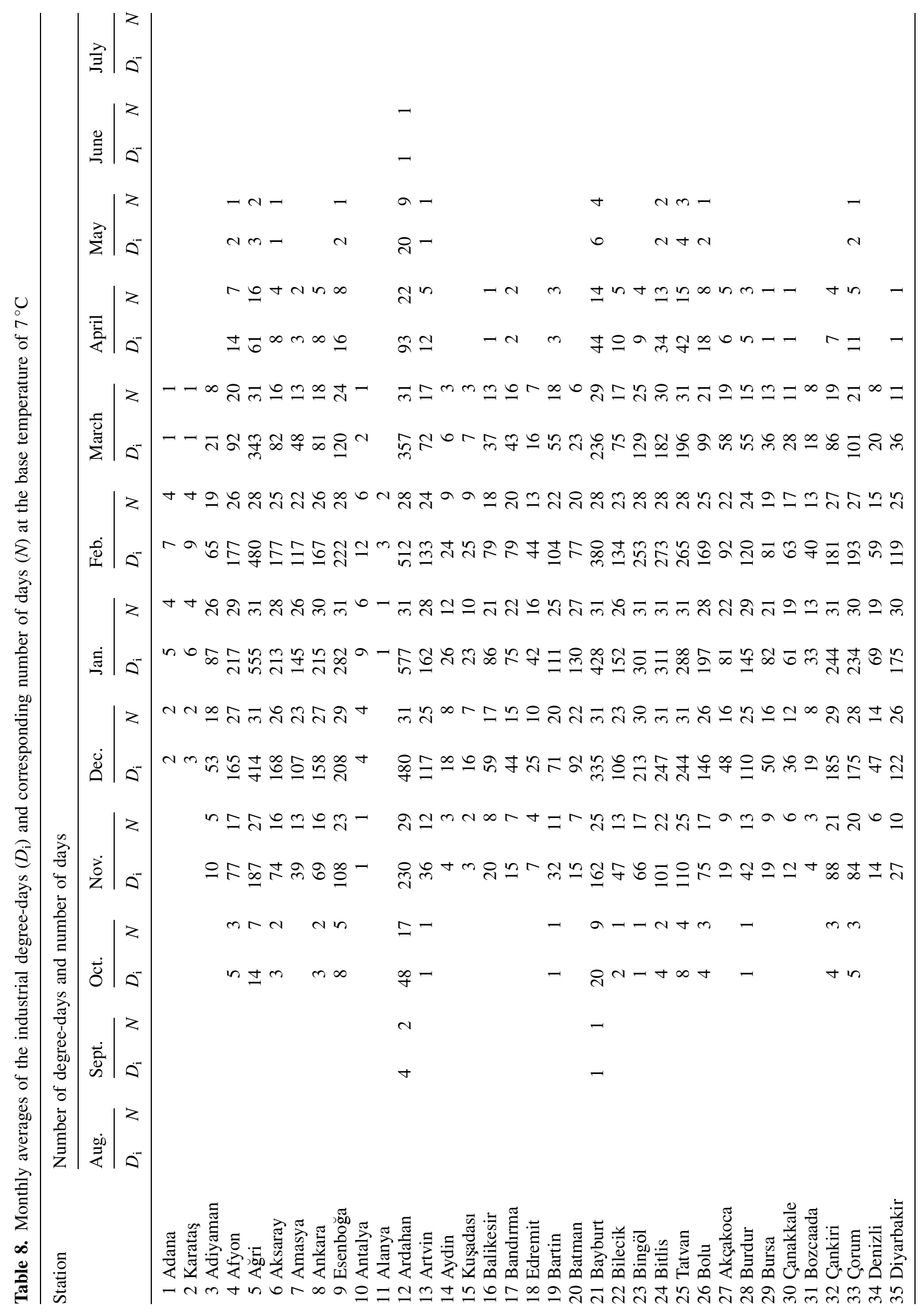




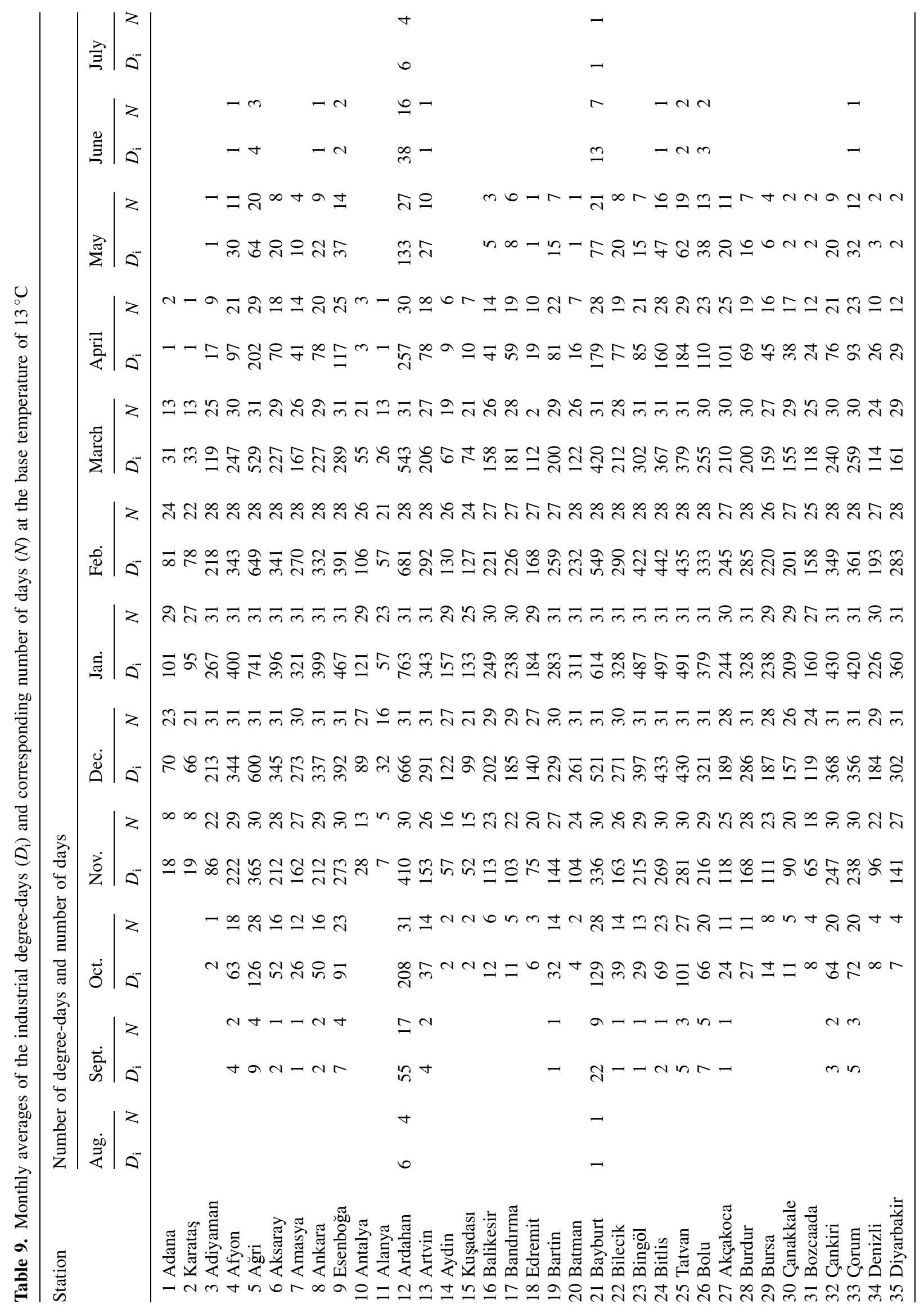


conditions, such as the eastern regions and high altitude areas of the central region of Turkey. For example, if Sarikamis $\left(D_{\mathrm{h}}=5566\right)$ and Iskenderun $\left(D_{\mathrm{h}}=516\right)$ are compared, assuming that the building orientations are the same, it is obvious that a residential dwelling at Sarikamis would have 11 times higher heating energy consumption than the very same building in Iskenderun.

\subsection{Cooling degree-days}

Table 4 shows the annual averages, and Tables 5 and 6 the monthly averages, of cooling degreedays $\left(D_{\mathrm{c}}\right)$ and the corresponding number of days which were determined for 100 different locations at the base temperatures of $18{ }^{\circ} \mathrm{C}$ and $24^{\circ} \mathrm{C}$. As Table 4 shows, the maximum $D_{\text {c }}$ had an accumulation of 1638 at the location of Sanliurfa, followed by other locations located in the same region; e.g. Adiyaman, Adana, Iskenderun, Batman, Siirt, and Mardin. In contrast, Ardahan, Kars, and Sarikamis had zero accumulations of cooling degree-days. Table 4 also shows that, even though the magnitudes varied, the degreeday accumulations at $24^{\circ} \mathrm{C}$ followed similar trends across the country. Tables 5 and 6 show that the maximum accumulation of cooling degree-days generally occurred in July. Exceptions are found in the Black Sea and Marmara regions where maximum accumulations are found in August. This variation can probably be explained by the effects of proximity to the sea and by latitude. Generally speaking, the cooling season extends from June to September; however, in some regions, the season also includes the months of May and October, and even April in some cases. As a result, across Turkey, no cooling is necessary for the five-month period from November through March, and at some locations no cooling is required throughout the entire year.

Based on the findings at the cooling base temperature of $18^{\circ} \mathrm{C}$, a total of four cooling regions have been identified for Turkey. These regions, and their corresponding numerical cooling degreeday ranges, are presented in Table 7 and the general spatial distributions are presented in Fig. 3. It should be noted however, that, if an exact figure is needed for a particular location, one should refer to the findings presented in Tables 4, 5 and 6 and not to the general distributions presented in Fig. 3.

\subsection{Industrial degree-days}

Table 8 shows the monthly averages of industrial degree-days $\left(D_{\mathrm{i}}\right)$ and their corresponding number of days which were determined for 100 different locations at the base temperatures of $7^{\circ} \mathrm{C}$ and $13^{\circ} \mathrm{C}$. Table 8 indicates that relatively high $D_{\mathrm{i}}$ values were observed at Ardahan, Sarikamis, Kars, Agri, and Erzurum, with values of 2322, 2141, 2088, 2057, and 2053, respectively. If very low monthly $D_{\mathrm{i}}$ accumulations are excluded, then almost all accumulations are found in an eight month period, with the most intense accumulations, occurring from December to February. In contrast, several locations revealed very small monthly $D_{\mathrm{i}}$ accumulations i.e., at Alanya, Iskenderun and Anamur, Mersin, Adana, Dalaman, Bodrum, and Silifke, with the latter five locations also having very low accumulated $D_{\mathrm{i}}$ values during very short periods. Table 9 , shows similar trends for the monthly $D_{\mathrm{i}}$ accumulations at the base temperature of $13{ }^{\circ} \mathrm{C}$ but with different magnitudes than those observed at $7{ }^{\circ} \mathrm{C}$.

\section{Conclusions}

As a result of this study, using the monthly distributions of heating, cooling, and industrial degree-days determined for corresponding base temperatures, one can easily estimate the heating and cooling energy consumption for any residential, commercial and industrial building, such as factories, greenhouses, and warehouses at any temporal scale (i.e. monthly, seasonal, etc.). This would also make it possible to compare and to suggest designs for alternative building systems in terms of energy efficiencies. If one prefers to use set point temperatures (sometimes there is no other choice) to indicate the resumption of the heating season, this would also be possible using the information provided in this article. Besides, manufacturing/marketing companies of HVAC systems, as well as utility companies, would be able to easily determine the demand, marketing strategies and policies based on the findings of this study.

\section{Acknowledgements}

The authors gratefully acknowledge the State Meteorological Service of Turkey (DMI) and Toraman Biothermal Systems Inc. of Canada for providing the data and partial funding, 
respectively. They would also like to extend their appreciation to the reviewers for their valuable suggestions.

\section{References}

Agriculture Canada (1993) Risk analyses of growing degreedays in Atlantic Canada. Research Branch Technical Bulletin 1993-5E, Ottawa, Canada

ASHRAE (1989) Handbook of Fundamentals, ASHRAE, Inc. Atlanta, GA 30329, U.S.A. pp 28.1-28.9

Bootsma A (1994) Long term (100 Yr) climatic trends for agriculture at selected locations in Canada. Climatic Change 26: $65-88$

Dagsoz KA (1995) Türkiye'de Derece-Gün Sayıları, Ulusal Enerji Tasarruf Politikası, Yapılarda Isı Yalıtımı. İzocam A.S.., Istanbul, Turkey

Edey SN (1980) Degres-jours de Croissance et Production des Cultures au Canada. Agriculture Canada Publication No. 1635, Ottawa, Canada

Environment Canada (1978) The climates of Canada for agriculture. The Canada Land Inventory Report No. 3, Ottawa, Canada

Environment Canada (1982) Canadian Climate Normals, 1951-1980. Volume 4 - Degree Days, Atmospheric Environment Service, Ottawa, Canada

Environment Canada (1987) The climate of Montreal. Ottawa, Canada, pp 36-39

Environment Canada (1988) Handbook on climate data sources of the atmospheric environment service, Ottawa, Canada, pp 3-5 and 3-6

Environment Canada (1990) Eastern Canadian Boreal and sub-Arctic Wetlands. In: A resource document. Ottawa, Canada

IPCC Working Group I (1991) Policy makers summary. In: Houghton JT, Jenkins GJ, Ephraums JJ (eds) Climate change: The IPCC Scientific Assessment. Cambridge, U.K.: Cambridge University Press

Kadioglu M (1997) Trends in surface air temperature data over Turkey. Int J Climatol 17: 511-520

Kadioglu M, Sen Z, Gultekin L (2001) Variations and trends in Turkish seasonal heating and cooling degree-days. Climate Change 49: 209-223

Lenihan JM, Neilson RP (1995) Canadian vegetation sensitivity to projected climatic change at three organizational levels. Climatic Change 38: 51-86

McKay GA, Mooney OR, Maybank J, Pelton WL (1967) The agricultural climate of Saskatchewan. Canada Department of Transport, Climatological Studies No. 10. Toronto, Canada

Neild RE, Seeley MW (1976) Applications of growing degree days in field corn production. In: Agrometeorology of the Maize (Corn) Crop. WMO - No. 481, Geneva, Switzerland, pp 426-436

Ramirez JM (1964) The agro-climatology of North Dakota. Part 1-Air temperature and growing degree days. North
Dakota State University, Extension Bulletin No. 15. Fargo, North Dakota, U.S.A.

Singh B, Maayar ME, Andre P, Bryant CR, Thouez JP (1988) Impacts of a Ghg-induced climate change on crop yields: effects of acceleration in maturation, moisture stress and optimal temperature. Climatic Change 38: $51-86$

Sykes MT, Prentice IC (1996) Climate change, Tree species distributions and forest dynamics: a case study in the mixed Conifer/Northern Hardwoods Zone of Northern Europe. Climatic Change 34: 161-177

Thomas MK (1953) Climatological Atlas of Canada. National Research Council Canada, Ottawa, Canada

Williams GDV, MacKay KH (1970) Tables of daily degreedays above or below any base temperature. Canadian Department of Agriculture, Publication No: 1409, Ottawa, Canada, 1970

Wilson CW (1973) The Climate of Quebec - The Application of Climatic Information - Part two. Environment Canada, Atmospheric Environment, Ottawa, Canada

Yener C, Gurdil F (1987) Türkiye Derece-Gün Değerlerinin Belirlenmesi ve Derece-Gün Yöntemi, TÜBITAK Yapı Araştırma Enstitüsü. Rapor No: H139, Ankara, Turkey

Yesilirmak E, Yildiz I (2001) Monthly and annual averages of growing degree-days at different base temperatures for Turkiye. GAP 2nd Agricultural Congress: October 24-26, Harran University, Sanliurfa, Turkey

Yildiz I (1998) HVAC Design in Turkish Greenhouses. Adnan Menderes University Publ. No: 6. Adnan Menderes University, Aydin, Turkey

Yildiz I, Yesilirmak E (1998) Turklim: Türkiye İklimsel Tasarım Kriterleri, I. Ege Bölgesi Tarım Kongresi, 7-11 Eylül, Aydin. T.C. Ziraat Bankası Genel Müdürlügü Basimevi, Ankara, Turkey, Cilt 2, pp 148-155

Yildiz I, Gürbüz T, Bozer S (1998) HVAC Designs for Livestock Buildings in Turkiye: Degree-Day Approach. Ege Bölgesi I. Tarım Kongresi, 7-11 Eylül 1998, Aydin. T.C. Ziraat Bankası Genel Müdürlügü Basimevi, Ankara, Turkey, Cilt 2: pp 164-172

Yildiz I, Yesilirmak E (2001) Monthly and annual averages of freezing and thawing degree-days and number of days for Turkiye. 20th National Congress on Agricultural Mechanization and Energy: September 13-15, Harran University, Sanliurfa, Turkey

Yildiz I, Sosaoglu B (2006) Tabulated distributions of heating, cooling, and industrial degree-days in Turkey. http:// cronus.uwindsor.ca / users / i / iyildiz/index.nsf /inToc/ DE7232EF7BA6FCC5852570A00060756D

Authors' addresses: Ilhami Yildiz (e-mail: iyildiz@ uwindsor.ca), Department of Earth Sciences, University of Windsor, Windsor, Ontario, Canada N9B 3P4; Betul Sosaoglu, Toraman Biothermal Systems Inc., Ancaster, Ontario, Canada L9K 1N5. 